\title{
Porch and Balcony in the Urban Landscape in the Painting of Safavid Period
}

\author{
Mohammad Ebrahim Zarei, Fereshteh Sharifi
}

Department of Archaeology, Bu-Ali University, Hamedan, Iran

\section{Email address:}

Ferershtehsharifi@Gmail.Com (F. Sharifi)

\section{To cite this article:}

Mohammad Ebrahim Zarei, Fereshteh Sharifi. Porch and Balcony in the Urban Landscape in the Painting of Safavid Period. International Journal of Architecture, Arts and Applications. Vol. 2, No. 4, 2016, pp. 20-25. doi: 10.11648/j.ijaaa.20160204.11

Received: October 18, 2016; Accepted: December 28, 2016; Published: January 24, 2017

\begin{abstract}
This study is analysed on the porch and balcony in safavid period, their role in shape and urban landscape during the period with selection of certain image. The research method in this study is based on visual reasoning and data were collected through visit of museum sites and books. The aim of this research is analysis of balcony aesthetic elements in the painting of safavid period and obtaining the outlook of the image and landscape in which porch and balcony were depicted in architecture. The questions in this study are; The images during safavid period, porch and balcony are shown and in which part of the building are they shown? what role do the urban landscape have? porch and balcony were used for what purpose and their function? Did the painter have any ideas about the porch and balcony in his paintings? Balcony was found in the upstairs but porch and verandas were found in the ground floor or basement. From urban landscape beauty is seen in the architecture and this is shown in the architecture beauty. porch and balcony were used by owners to sit and relax, the result show that balcony and porch in this image is accordance with principle of discipline and taking into consideration the perspective are shown in the sample of the paintings, they are signs of importance and place of this part is in the exterior view in the Iranian architecture and generally manisfested in touch of nature and romance.
\end{abstract}

Keywords: Porch, Miniature Paintings, Safavid Period, Urban Landscape

\section{Introduction}

The use of porch in the pre-Islamic history of Iranian architecture trace back to pre-Islam. During the Islamic period it is also considered different. Most of the porch were destroyed because of the lightweight materials used in most of them. Painting can be an important source for studying and reconstructing this type of spaces. Persian Painting can be divided into four categories; Painting in book, Painting on objects, frescoes, single-painting in this study painting books (manuscripts) are considered. The emergence of what is now known Iranian painting in book illustration is depicted more to the kings and princes. In miniature vogue till safavid period, most of them have been limited. And other types of painting although it existed before but it flourished again after the Safavi era, in this study painting are considered the architecture and it is depicted in it. Porch is usually in the form of manuscripts, paintings of architecture or town in which the main theme is painting and other paintings are the subject occurs in a location that the porch can be seen more in the second floor. In many paintings the main objective of the painter narrates an event, story or myth, and thus often implicit architectural space and is considered secondary. While in some paintings, most of the paintings are dedicated to architectural space. In this study three questions that would be answered in the review process is considered: First, in painting during Safavi period, porch and balcony are portrayed which emerged in parts of buildings and what role they had in the urban landscape? Porch and balcony were in what order, and it has been used for what purpose? Did the painter have pictures in implementing porch and balcony on lighting? More balconies were seen on the upper floors but porch and verandas were found on the ground floor and basement also the picture of the urban landscape or architectural space has a certain beauty to the home and the importance of this space in architecture. Porch and balcony were used to sit at times by some people who are homeowners, the results show that porch and balcony is depicted in this paintings in accordance with the order of the principles and perspective in most cases. 
Research Methodology: This research is descriptive and analytical history and is based on Library and visit the site museums where paintings were exhibited.

Literature of research: About porch painting has not been done. But about the architecture in painting,research has been done Including most notably, how to understand the architectural space of the Persian painting (Foroutan, 2009) architectural language Persian painting (Foroutan, 2010) architectural and urban spaces in Iranian painting (Soltanzadeh, 1999) can be cited.

\section{The Architecture of the Safavid Period}

The activity of the architect, during Shah Abbas I in Safavid period began. During this period, not only in Isfahan, but also in Shiraz, Ardabil, Mashhad, Tabriz and other Iranian cities in different buildings were constructed. In Safavid period Iran was renewed architectural style and building design, shape and materials opened his own place. Most of Safavid period buildings such as mosques, schools, and the inn was built in four porches (Kayani, 2014: 105). Iran has several architectural styles, architectural style Safavid period, placed in the Isfahan. This style pre-Safavid period to Qajar period begins and continues. Pirniyais summarized Isfahan features as follows: The simplicity of the designs used in most buildings, spaces, square or rectangular, simple geometry and shape of the broken line and is used in more Isfahan style,beveled edges were common in the building, utilizing the buildings, it has been considered in the same size and simplicity of design and they are evident in buildings (Pirniya, 2008: 279). Safavid period architecture supported by Safavid kings and the result of this support, architectural masterpieces that remain from this period.

\section{Painting in the Islamic Period}

Painting in the early Islamic originates from art of occupied areas especially Egypt, Syria, Central Asia and Iran and major part of the painting belongs to the art of preIslamic Iran (James, 210: 38). The first samples of Iranian paintings dated to the late seventh century AH. Painting remained there before the seventh century $\mathrm{AH}$. The reasons for the lack of this drawing, are the destruction of humans, paintings, walls, palaces and sometimes erosion and natural disasters, especially on paper drawings (manuscripts) is (Pope, 1998: 75). The second half of the eighth century AD, following the crash of Ilkhanan in Iran the country had restless turbulent times in this period, the history of panting as well as complexity of the political history of this period (Grabar, 2003: 52). But at the end of the eighth century AD Iran was completely dominated by Timor and over one hundred years of classical paintings were at the best of their time and talent because of the feelings of the art of prince (James, 210: 47). A large painting of Ilkhani era and the Timurid, Safavi still remains, in which architecture is impressive (Foroutan, 2005: 75). The Ilkhani and Timor era shows a perspective better space and depth is used then.
(Foroutan, 2005: 70). At the beginning of the Tenth century Safavi coincides with the formation of a strong government. Shah Ismail 1 (930-906 AD.) art lovers and then art flourished. After repelling the enemy and bringing peace and tranquility in the country, many artists and artisans gathered at his capital of Tabriz. Painting School of Tabriz, the Safavi government 's support was based on the achievements of Turkmen arts and school of Herat was glorious. "Main legacy of Shah Ismail, the legitimation of Shiism in Iran created a kind of homogeneity and unity of the visual arts in Iran and added the prosperity and richness to Tabriz painting" (Azhand, 2005:23). The real flourishing was seen in the late 30 th century AH Painting School of Tabriz. Paintings of this period show a steady increase over the years through Behzad school.

Attributes such as changes in characterization, trying to enliven and associate them with the surrounding environment, the environment was much harder to build into more realistic, their influence and outcomes were proved (Ashrafi, 2005, 48). Shah Tahmasp, who learned from his father was rearing art painting at Tabriz school he boomed and protected the Tabriz style and it played an important role. He had a special attraction for arts. In the first half of his reign (957- $930 \mathrm{AD})$. He introduced the best artists and artisans and he collected all of them in his painting workshop. Brilliant era of Tabriz school in the second half of the Shah Tahmasp (984-957 AH) began to wane. In the year 955 AD. Shah Tahmasp after transferring the capital to Qazvin, he changed his opinion about arts and he no longer supported the artists. After that the artists moved to India when the king of Gurkhani invited them.

\section{Features of Painting and Miniatures in Safavid School of Painting}

Painting is also defined as Miniatures,it is the root of manuscript, writing and drawing, The big school-such as Abbas (Baghdad), Mughal school and attended school in Herat and with the rise of the Safavid and with the support of artists of miniatures it flourished. The important art of painting among other arts and paintings, with the correct use of color, form and space is one of the most successful ways to express the link between reasonable and sensible world. (Tajvidi, 2007: 13). The most important function of Persian painting create a sense of illustration. This means that an objective picture of a special occasion offers, to understand it in terms of visual sensory pleasures associated with confined space accidents image. (Bynyvn et al., 2005: 23). In the Safavi period, three important painting school were the main ones as Tabriz, Mashhad, Bukhara.

\subsection{Tabriz School}

Tabriz School which was established during Safavi period was interest from various sources: Turkoman school itself two main styles: it means that school of Shiraz Pyrbdaq Aghkoyunlular and Sultan Khalil, who owned the Timurian 
era were artistic tradition and Tabriz school and period of Jahan shah Gharaghvianlu and king Yaghub Aghghaviunlu with artists such as Sultan Muhammad Tabrizi, and school of Herat during Sultan Hussein Bāyqarā period with prominent artists such as Behzad until the year $942 \mathrm{AH}$ he was alive and Shah Tamaz and shah Esmael supported Behzad and he was the chief libranian of the Royal library( Azhand,2005: 102)

\subsection{Mashhad School}

At a time when Qazvin was the capital, the nephew of King Tahmasp was appointed as the governor of Khorasan. Workshop held in Mashhad, in addition to the artists residing in Khorasan, Tabriz school teachers were also recruited. The painting looks fresh in Mashhad. emphasizing color and diverse rhythm lines and white spots that have given momentum to the scene, soft lines and curves were clearly superior (Maleki, 2008: 77).

\subsection{Bukhara School}

Painting School Herat branch of the Bukhara school can be outlined, That after the year $913 \mathrm{AH}$ and Uzbeks attacked in Herat and the mass exodus of artists were gathered in Bukhara and Samarkand and Tashkent. Mohammad Sheibani who robbed some precious books from the Royal Library of Herat and manpower Herat school moved to Bukhara, in order to support the arts, crafts and architecture (Azhand, 1386: 33). since16th/ 9 AD century up to the present day miniatures remain and it shows the extent of the Art visualization book in Bukhara. Most of these effects have high quality and professional skills (Ashraf, 1382: 162). Best painter and apparently the master painters of school known as Bokhar is Mahmoud Mazhab and is signed by the same name (Basil, 1383: 281).

\section{Porch and Balcony}

Most researchers knows porch type of vaulted (porch is little deep and it has relatively wide arch) from the front yard or garden or out they are fully open. At the core of the building it can be placed and may be placed to another part that have access to the building. porch as a semi-open space that comes in various and rewarding experiences of spatial perception and it brings understanding of nature. In terms of form, size and position can be studied in architecture (Mahmudi, 2005: 53). The difference of balcony with porch, porch in Farsi, is part of the building that has roofs and sometimes with three sides surrounded by walls but are attached to the open air and in architecture, it is called the semi-open space. After entering the west styles of construction in Iran, it is foreign name but it entered Persian. To day it is called porch, terrace or balcony, but there are subtle differences in their literal meaning. In English, the terrace is named to each flat tall or the so-called platform. but the balcony,is high-level half way connected to the exterior of the building and is surrounded by a low wall or railing and is closer to the definition porch.

\section{Planning Index with Porch and Balcony}

A few examples of where the balcony and porch image is depicted, here they are described. Painting was destroyed by Zahhak rich Tahmasp Shahnameh, Tabriz attributed to Sultan Muhammad, in this image, but also a balcony on the building side view is depicted. Materials of wood and the roof is covered with a canopy. The Painting of the painter wanted to portray the architectural space into a garden balcony roof which is not flat, but the roof, this painting tells a story through a garden for this reason, the balcony has a gable roof like (Figure 1). In Painting Sheikh Sanan and daughter Teresa, Tabriz attributed to Sheikhzadeh, balcony was depicted over the entrance in the painting and what image comes from the materials is that it is made entirely of wood. Decorating floor like a staircase seen in Ali Qapu Palace in Isfahan. The Painting there show graphical images of women so the balcony of spaces were suitable for women in those time (Fig 2). Painting House of Solomon and Bilqis from Haft orange Jamin, Mashhad. Between 963-78 AD Freer Gallery of Art in Washington. This painting is included in the balcony above the entrance. On the one hand it is only open on three sides and the other side is closed and it is also visible in a window, In the majority of Mashhad school of painting that depicted the balcony where this balcony is an enclosed space (Figure 3).

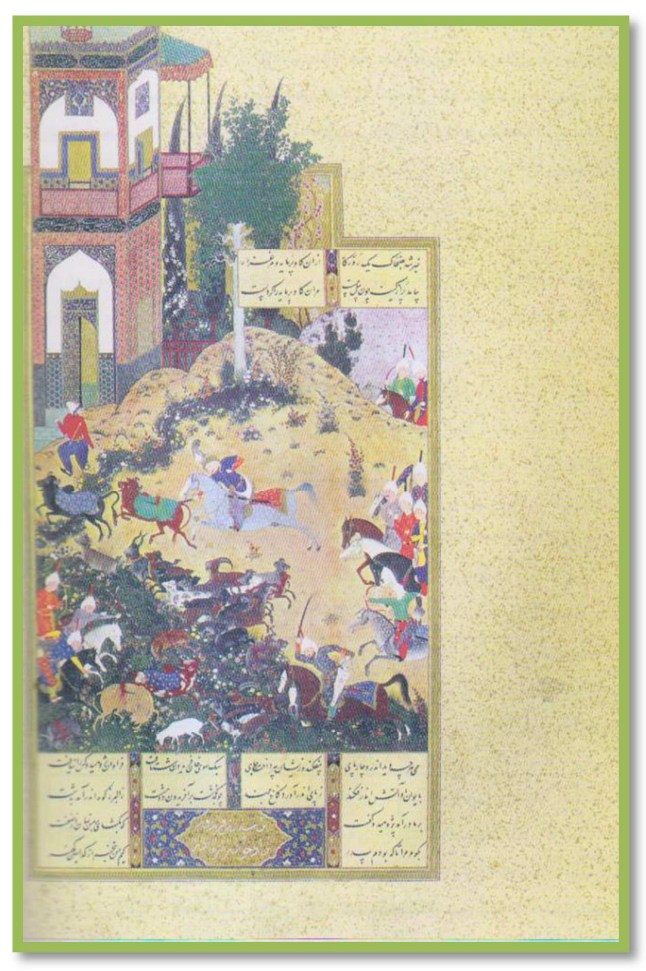

Figure 1. Zahhak rich Tahmasp Shahnameh, Tabriz attributed to Sultan Muhammad(azhand:1384,42). 


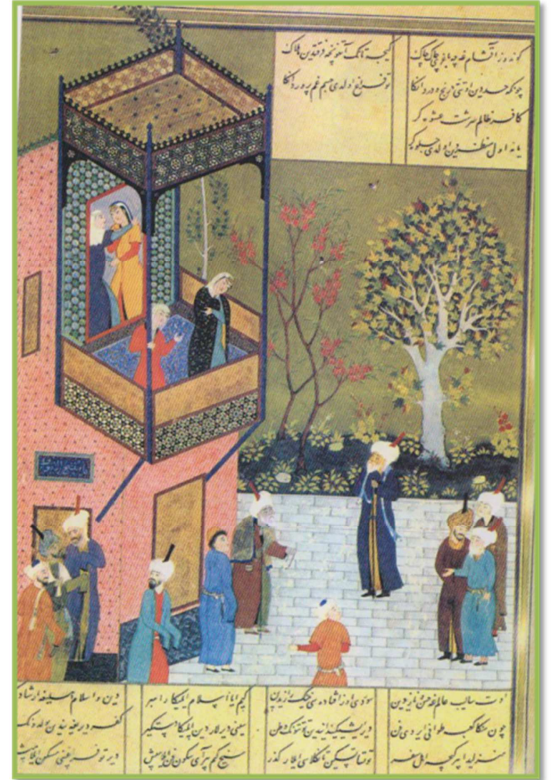

Figure 2. Painting Sheikh Sanan and daughter Teresa, Tabriz attributed to Sheikhzadeh, balcony was depicted over the entrance.

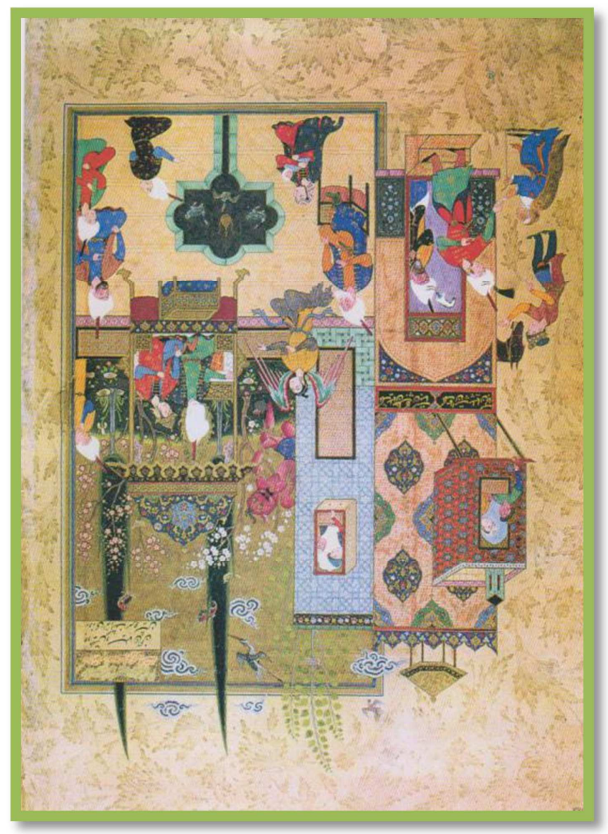

Figure 3. Painting House of Solomon and Bilqis from Haft orange Jamin, Mashhad. Between 963-78 AD Freer Gallery of Art in Washington. (Azhand:1384, 211).

On the wedding night Khosrow and Shirin owned 933 paintings attributed to Sheikhzade fromTabriz, In this painting the porch has columns the main space is a platform porch with low altitude of the yard and is located and the columns have been on the podium. Elegance and thin columns indicate that columns were made from wood and with pedestals shaped pot. Examples of these types of columns can be seen in the palace and is quite similar to the Safavi era. The sample frame is also decorated with its provisions and clauses porch roof frame Alighapoo comparable (Figure 4).

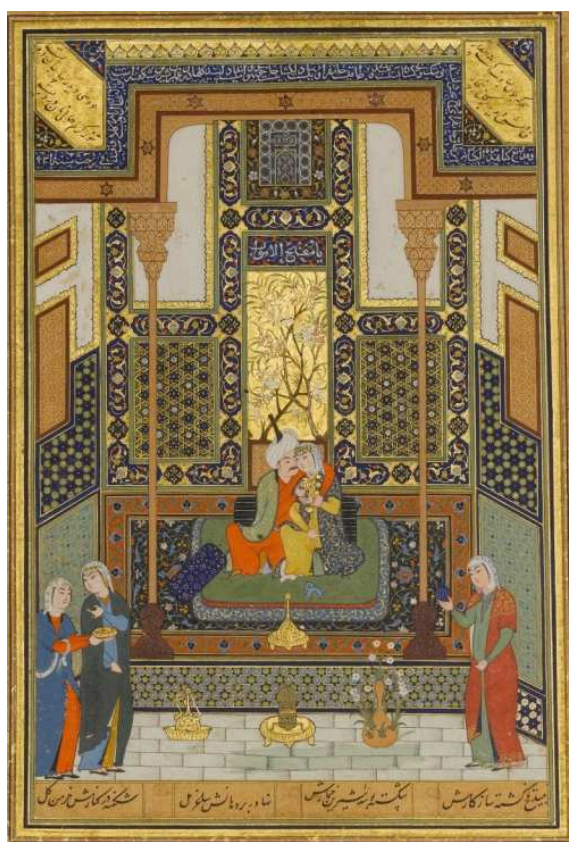

Figure 4. Marriage of Khosrow and Shirin" Folio from a Khamsa (Quintet) of Nizami. Calligrapher: Artist: Painting by Shaikh Zada. present-dayHerat. - The Metropolitan Museum of Arts (www.peopleofar.com).

Kay Khosrow paintings gives the crown to Lohrasb, in $1023 \mathrm{AH}$, this painting was the imitation of his father's paintings in the coffin mourning 833 , LH. In this painting the base of the columns of porch is probably of stone in the form of pot, Columns, such as wood samples, have been illustrated very thin it seems to depict the building of the castle. However, at the Palace of Eight Paradises of Isfahan these congresses have been used (Figure 5).

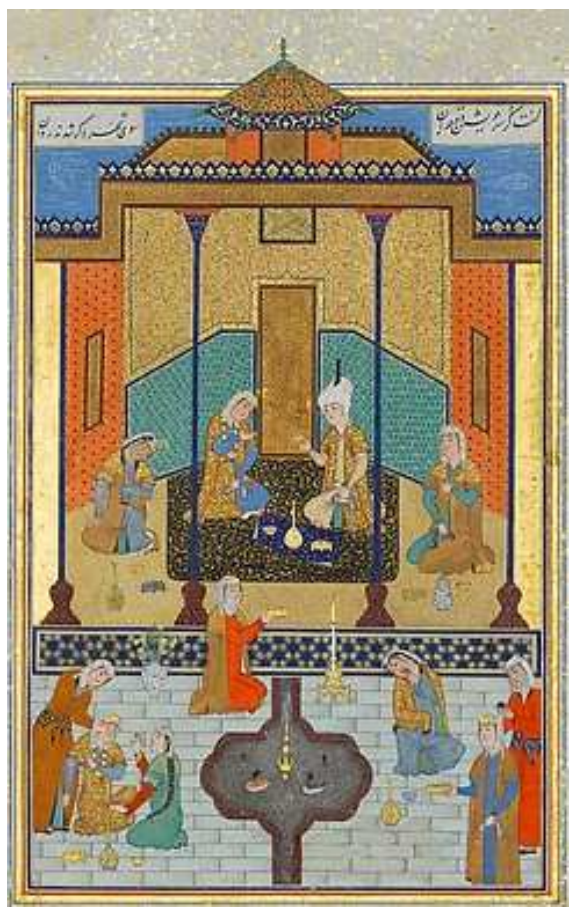

Figure 5. Nizami (Muhammad Nizam al-Din of Ganja) Painting by Shaikh Zada(www.metmuseum.org). 


\section{Analysis of Paintings}

Applying geometric system that has a long history in paintings, which is taken into consideration. The most important thing about finding the frame and main divisions within it. (Haseli, 1998:16). The Iranian painter's image of an artificial environment is seen in all samples drawing of a scene of regular geometric structure. Even they are seen in the details reliefs on surfaces of building strict compliance with surface size, in order to illustrate areas of wall and floor surfaces they are used in a geometrical proportion to each other as architects could perform any work of art by a proportional and orchestrated system. This idea of "harmony" is the central point of thinking for most Muslim philosophers. In this way geometry is used for poetry, Structural and decorative are integrated everywhere: Royal scale, harmonious proportions, rich and bright in colors, all combined in the perfect balance and the building has a unique appearance. (Pope, A. 1998) Observe the perspective in the implementation of balcony in the paintings, the testimony of the recognition of the artists of that period, from proportion of appropriate size in design that this point has been adopted somewhat in the school paintings of Guarani. Loyalty to the original style of Iranian dimensional processing is an important principle in school paintings. paintings are an important part of the video sources. Considering what painters have depicted, what he saw at his time, cannot be assumed from these images and they are completely different from reality. Balcony picture in painting in the direction or directions in which has good prospects to the vast and often include the outer landscapes and nature (garden, mountain). Porch is used as a separator between the original space and outer space climates in the cold areas and to avoid extreme cold and heat, to avoid heat zones in the various parts of building, which is practical and that gives the building special beauty and it has the index. Porch, was used as the main space, the paintings confirm this and a balcony with respect to the original painting, which is a space for sitting and communicating with the outside. It seems that the balcony space is generally easier to establish communication with the outside (the enjoyment of nature and describe scenes and landscapes). Artist painter in most cases in implementing the balcony image pay attention to fit and dimensional processing and this shows the artist's vantage point. SThere is diversity in the choice of houses and this explains the artist's freedom in selecting the best scene in the narrative description text. Paintings, often the richest literary structure of the order which have been included in their heart, this ensures the highest picture rich with meaning and is supposed to be managed in a coordinated and text descriptions. Material that has been used on the porch are lightweight materials such as wood because porch and balcony as an additional space has been visible in the painting, especially the balcony made by wood and in most of them is decorated with drawings on wood and the porch columns and column headers, the wood and the stone pedestal in the form of pot and the terrace is in the yard and a little height on the columns of porch and porch is in fact the original space where the materials are used in the building for the terrace.

\section{Conclusion}

According to the painting and its stories, balcony can be seen further in public buildings, balcony modeled pavilions that have been made are on the ground floor in the garden, later in the upper floors of buildings and it is as part of the architecture it is used as space to relax and sit for homeowners and their relationship with the outside. The image balconies with respect to the location where the miniature has been portrayed differently and the reason is that the painter follows the addition of a special school, the architecture has used the same areas. As you can see in the miniature Bilqis more miniatures which emerged in Mashhad school, protruding balconies exponentially but in most areas it is closed and the reason is that school is where it is originated, architecture is closed and introverted but more porch appeared on houses, castles and royal palace and the house was used mainly for office meetings which were held in it. In comparing these painting with the palace and the palace of Safavi shows that the painter has used to portray the porch of the building. Furthmore because of these spaces and their light materials, they were destroyed over time and few traces remain of the porch. The miniatures of these spaces are good for rebuilding. The urban landscape also has porch and balcony they are as an embedded space, has given a certain beautiful building,this embedded spacewere built of lightweight materials and low-cost,Apart from Pretty impressive they have different functions and to take advantage of the building's owner.

\section{References}

[1] Azhand, Y. 2005. Painting School Tabriz, Qazvin and Mashhad. Tehran: Academy of Art.

[2] Ashrafi, MM, 2005, the evolution of 16th century Persian painting. translating $\mathrm{N}$ Zandi, Tehran: Academy of Art.

[3] Bennion, Lawrence, Wilkinson, J. v. s and Gary, Basil, 2005, the course of history of Persian painting, Mohammed Iranmanesh, Tehran, Amir Kabir.

[4] Bynyvn, Lawrence, Wilkinson, vol. And. Q. And Gary, Bazyl. 1988. history of Persian painting, translated by Mohammad AyranmshTehran. Amir kabir.

[5] Haseli, P, 1998, expressions of architecture in miniature, Art Monthly, No. 16 (p. 16).

[6] James David, 2010, Introduction to Islamic Art, translated by Mohammad Ebrahim Zarei, Hamedan: Bu-Ali Sina University Press.

[7] Kiani. M. Y, 2014, Iranian Architecture of the Islamic Period, Tehran, Samt Publication.

[8] Forotan, M. 2005 "Understanding Iranian Persian Painting of the structure of architectural space" Fancy, No. 13, (S83-71). 
[9] Grabar, Alec, 2005, a review of the Persian Painting, translated by Mehrdad Vahdati danshmand, Tehran: Academy of Art.

[10] Gray, BasilT, 2004, Iranian paintings, translation Sharveh, Tehran, publisher of the New World.

[11] Mahmoudi, A, 2005, review of Ivan the traditional Khanh Hay, fine arts publication, Issue 22 (p 53-62).

[12] Maleki, Tuka, the trend of painting in Iran, Tehran: the Moon and art (72-79).

[13] Pope, A1998, garlic Portrait of Persian painting, translation Azhand, Tehran: Molly.
[14] Pirnya. M, 2009, Style of Iranian architecture, Tehran, Sorosh Danesh publication.

[15] Sltan Zadeh, H, 2008. architecture and urban space in painting, Tehran: tagh.

[16] Tajvidi, A., 2007, at the Art Iran (since the beginning of the tenth century), Tehran, Printing and Publishing Ministry of Culture and Islamic Guidance.

[17] www.metmuseum.org

[18] www.peopleofar.com 